\title{
Corporate Social Responsibility in the Garment Industry. The Case of the Clean Clothes Campaign and Developing States
}

Tomasz Wawrzyniak*

\section{Introduction}

Corporate Social Responsibility (CSR) is a topic which has been gaining in popularity over the last few years. Put simply, it refers to the idea that the main purpose of businesses, alongside making a profit, should be to behave in a socially responsible way, recognizing the impact they have on societies as well as on their whole supply chain. They should therefore design such policies which would allow them to follow not only selfish goals, but also aim for the good of the general environment as well as society. This refers in particular to corporations which reach beyond national borders, as they have the greatest influence on their clients and employees. CSR has certainly become a more recognizable idea thanks to many organizations whose purposes include raising social awareness in areas where firms show negligence of CSR. This disregard of social responsibility is very often seen in multinational corporations in the textile and clothing industry, as they turn to developing countries and exploit the often uneducated, cheap labour force. One of the organizations which is trying to fight against this practice is the Clean Clothes Campaign (later: CCC or the campaign). The purpose of this work is to briefly discuss the poor situation of developing states and then focus on explaining the position, goals and activities of the CCC in dealing with this phenomenon. As such, the article will try to provide arguments for the hypothesis that the idea of CSR, and consequently the existence of organizations such as the CCC that stand in its defence, is relevant and, although slowly, it is having an effect.

\footnotetext{
* Tomasz Wawrzyniak - student, University of Lodz, Faculty of Economics and Sociology, Field of studies: Economics and International Business, tomek1992@wp.pl.
} 


\section{The situation in developing countries}

Only a few years ago, if asked what country is most associated with a cheap labour force, most people would have answered China. However, this image is slowly fading as China is steadily becoming a prominent economy, one which could stand alongside such powers as the United States or Germany. The living conditions are improving as China follows the communist ideology politically, but is reasonably capitalistic when it comes to the market. This has left Western corporations looking for other countries which could provide them with an advantage in the form of a cheap workforce. One such country is Bangladesh.

Bangladesh is figuratively and literally "squeezed" between India and Burma on a relatively small area of 148,000 square kilometres. It has a population of around 156 million, creating a huge overpopulation problem which makes Bangladesh a country with one of the highest population densities in the world (The CIA World Factbook, 2016). Data concerning the GDP growth of the country show that it has kept steady at around 5\% for the last several years (Trading Economics, Bangladesh). This does not reflect the factual situation in which the country is present. According to the CIA World Factbook (2016) Bangladesh is suffering: "political instability, poor infrastructure, corruption, insufficient power supplies, slow implementation of economic reforms". The growth is mainly boosted by foreign corporations, mainly ones within the textile and clothing industry, outsourcing their production to Bangladesh. It is overwhelmingly visible in Figure 1, which presents the exports of Bangladesh. Almost 94\% of them are textile products.

Figure 1. Bangladesh exports - visual representation (2012)

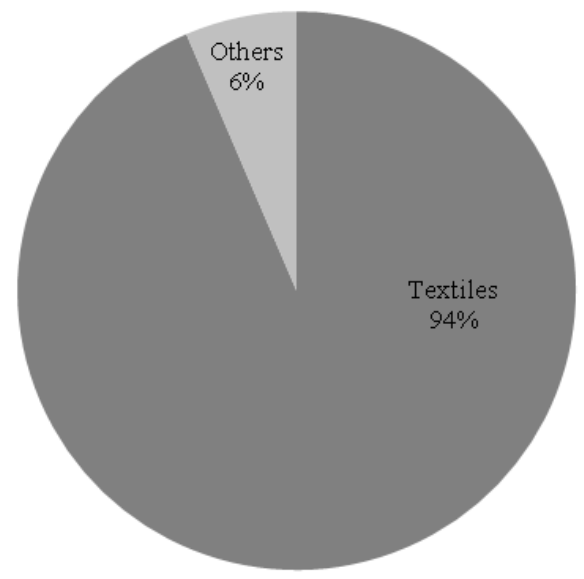

Source: own work adapted from data of The Observatory of Economic Complexity. 
The state of the unemployed in Bangladesh is also fallacious (Table 1). The data from the Bangladesh Bureau of Statistics (BBS) shows that total unemployment is $4.5 \%$ (Bangladesh Bureau of Statistics, 2011). This is a very low number and it should naturally raise suspicion, considering the overall poor condition of the country.

Table 1. Bangladesh unemployment rate by age and sex (2010)

\begin{tabular}{|c|c|c|c|c|c|c|c|c|c|}
\hline \multirow{2}{*}{$\begin{array}{c}\text { Age } \\
\text { group }\end{array}$} & \multicolumn{3}{|c|}{ Bangladesh } & \multicolumn{3}{c|}{ Urban } & \multicolumn{3}{c|}{ Rural } \\
\cline { 2 - 11 } & Total & Male & Female & Total & Male & Female & Total & Male & Female \\
\hline Total & 4.5 & 4.1 & 5.7 & 6.5 & 5.7 & 8.3 & 4.0 & 3.6 & 4.9 \\
\hline $15-19$ & 10.6 & 9.8 & 11.4 & 12.4 & 11.7 & 13.4 & 10.1 & 9.8 & 10.6 \\
\hline $20-24$ & 7.1 & 6.8 & 7.7 & 9.9 & 8.7 & 11.5 & 6.3 & 6.2 & 6.4 \\
\hline $25-29$ & 5.4 & 4.3 & 7.3 & 7.9 & 6.3 & 10.8 & 4.6 & 3.7 & 6.2 \\
\hline $30-34$ & 4.2 & 3.8 & 4.8 & 5.6 & 5.0 & 6.9 & 3.6 & 3.4 & 4.0 \\
\hline $35+$ & 2.4 & 2.4 & 2.7 & 3.9 & 3.9 & 3.8 & 2.0 & 1.9 & 2.4 \\
\hline
\end{tabular}

Source: adapted from the Bangladesh Bureau of Statistics (2011).

There are other parts concerning unemployment that have to be accounted for in the welfare of Bangladesh. These are underemployment and the employment of unpaid family members. According to an analysis of the BBS (2011), 20\% of the employed are subject to this underemployment. Of course, this is not equally distributed between men and women, as $14.40 \%$ of the employed male population work under 35 hours a week, and in the case of women it is $34.15 \%$.

When the above-mentioned data are combined with wages and the unhealthy, sometimes dangerous working conditions, a rather poor picture of the situation of Bangladeshi workers emerges. The minimum wage set by the National Minimum Wage Board of Bangladesh is an extremely low 1500 taka (USD 18.75). For the garment industry, it was set at 5300 taka (USD 66.25). This is still a very low amount as "The centre for Policy Dialogue, an independent think tank, reported a monthly wage of 6,500 taka (USD 81.25) was reasonable to cover living expenses." (US Department of State 2013). What is more, despite the government's attempts at regulating wages and working conditions, it "(...) did not effectively enforce minimum wage, hours of work, and occupational safety and health standards in all sectors. Resources, inspections, and remediation were not adequate, and penalties for violations were not sufficient to deter violations" (US Department of State 2013).

Another country that could be used as a representative of the maltreatment of workers, specifically in the garment industry, is Cambodia. It is a Southeast Asian country situated between Thailand, Vietnam and Laos. The total area is 
$181,035 \mathrm{~km}^{2}$, with a population of 15,458,332 (The CIA World Factbook, 2016). Like Bangladesh, Cambodia's GDP has grown steadily over recent years (Trading Economics, Cambodia) and this is also in large part attributed to an export-oriented garment and footwear industry being situated in the country. Again, it can be clearly seen in Figure 2 how the clothing and textile branch dominates as a category of exports in Cambodia.

Figure 2. Visual representation of Cambodia's exports (2012)

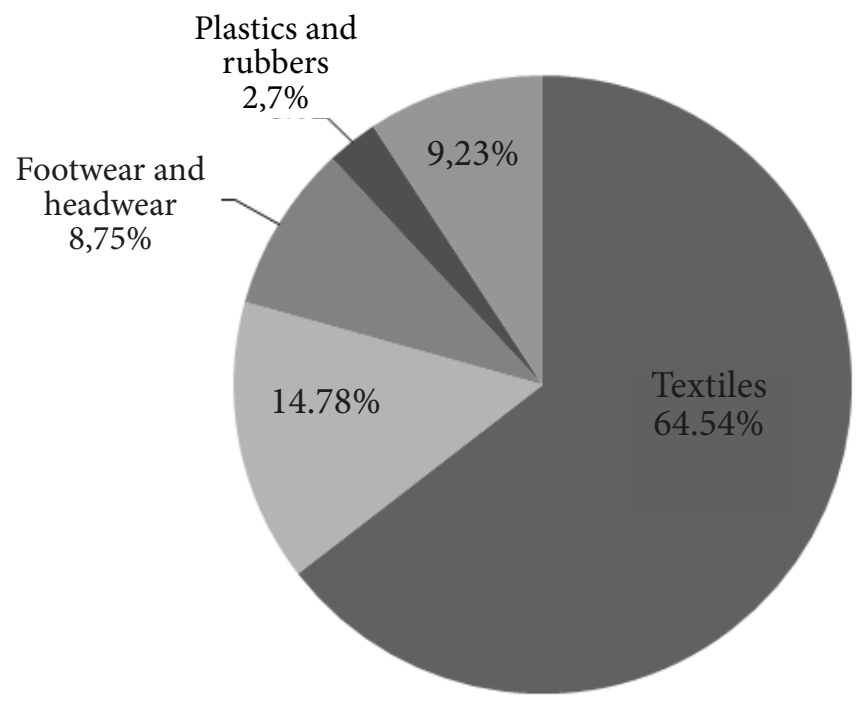

Source: own work adapted from the data of The Observatory of Economic Complexity.

One aspect of the Cambodian economy that is particularly stunning is the unemployment level in the country. Over the last few years it stayed below $1 \%$, never getting higher, and for 2014, annual unemployment was $0.3 \%$ (Trading Economics, Cambodia). But this value is fallacious. Not in the same manner as the data from Bangladesh (where the main attribute was underemployment) but because of two elements. The first is that Cambodians cannot afford to look for the job they want. Cambodia does not have unemployment benefits, so workers often have to accept whatever offer they can in order to survive. The second factor is the so-called "vulnerable employment". This is unpaid family workers or those who are self-employed. Recent data is unfortunately lacking, but in a 2010 report from Cambodia's National Institute of Statistics (2010) (compiled together with the International Labour Organization), over $80 \%$ of total employment was this "vulnerable employment". This informal sector of unemployment is not in any way regulated by law and oftentimes provides a very low income to the worker. 
Finally, there is no legally specified mandatory minimum wage established for all sectors of the economy. The only sector that the Ministry of Labour and Vocational Training is obligated to set a minimum wage for is the Garment and Footwear industries (because of pressure from the Western world). The most recent wage improvement for this sector reached USD 128 (Clean Clothes Campaign 2014).

\section{The Clean Clothes Campaign and associates}

The name of the campaign reflects its general purpose: campaigning for the rights of workers of the garment industry and pressurizing corporations to recognize their social responsibility, not only in their home country, but also along the whole supply chain. The CCC forms an alliance of organizations in 16 European countries: trade and labour unions, non-governmental organizations (NGO's) and other associates. Outside Europe it is a partner to over 200 organizations. The campaign was founded in 1989 in the Netherlands around a solidarity action for female workers in Philippines. Its statutory goal is to: "educate and mobilise consumers, lobby companies and governments, and offer direct solidarity support to workers as they fight for their rights and demand better working conditions" (Clean Clothes Campaign, 2017). The structure of the campaign is presented concisely in Figure 3. The CCC "headquarters" is divided into a Bureau (administrative support), the Dutch Secretariat, and an International Secretariat (coordinating European CCC coalitions and the partnership network). Most of the local campaigns follow a similar pattern. In Poland, for example, Clean Clothes Poland (CCP) is constructed of 4 previously existing organizations which, since the launch of CCP, have been assigned different tasks (the Karat coalition acts as the local secretariat, and the Polish Humanitarian Organization educates the public on human rights). Apart from the European associates, the CCC's reach extends to Australia, the USA and indeed even to Asia. The campaign cooperates with Oxfam Australia, the Asia Floor Wage Alliance, United Students Against Sweatshops ${ }^{1}$ or the International Labour Rights Forum. Once again, all of them strive collectively for goals overlapping those set by the CCC.

Besides working with worldwide organizations, the CCC seeks the cooperation of European Union (EU) bodies in their campaign. Until recently, the only action from the EU was the support of many $\mathrm{CCC}$ undertakings and publications. Since the CCC has started to gain renown in their campaigning, EU organs have recognized their expertise in the field of CSR, specifically the outsourcing of production to developing states by Western clothing and textile industry corporations.

\footnotetext{
${ }^{1}$ Sweatshop is a term describing a workplace with unhealthy, socially unacceptable and dangerous working conditions. It may also involve child labour.
} 
Figure 3. Organizational structure of the Clean Clothes Campaign

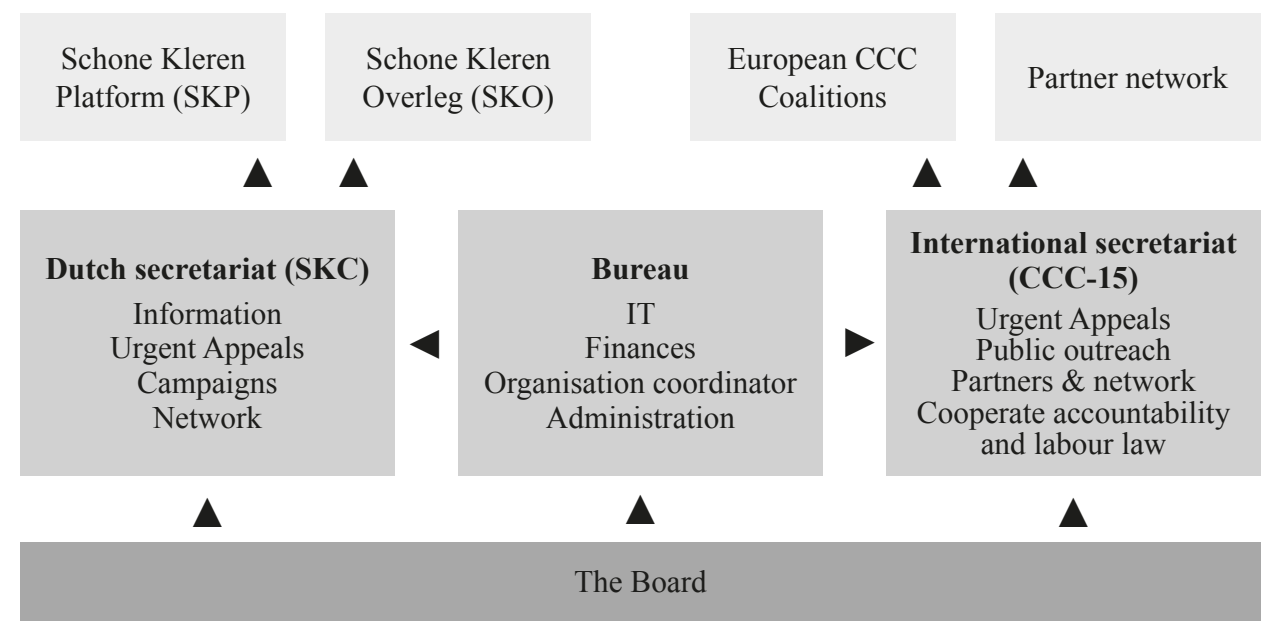

* $\boldsymbol{\Lambda}=$ provides services to.

Schone Kleren - Dutch for Clean Clothes

Source: Clean Clothes Campaign (2011).

The CCC has been invited to join the EU flagship initiative on management of the supply chain in the garment sector (later, the initiative). Its main goals would be to raise awareness (of both consumers and companies) about issues concerning negligence of responsibility in the supply chain, strengthening coordination between units that already operate in this area, and encouraging all of those involved to develop a proper response with the help of tools already available, such as policies, norms, regulations, etc. (European Commission, 2014). The CCC's (2015b) main suggestion towards realizing this initiative is to introduce the office of an ombudsperson. Such an office (build in accordance with existing EU laws) would have 3 main responsibilities:

1) The systematic assessment of the whole supply chains of Western corporations and making sure that the human rights of all actors are respected. In this way, the ombudsperson should have a level of independence and an authority that would allow that person to conduct proper research in the area.

2) Respecting workers' rights to reparation as victims of abuse in the industry. The ombudsperson's office would superintend the process leading to full remuneration for the victims.

3) Counteracting human rights abuse, whether they are carried out by corporations or countries, and administering proper sanctions for the offenders. 


\section{The CCC's goals and activities}

Before getting involved in the EU project and gaining some, if even marginal, leverage and say in the EU initiative, the $\mathrm{CCC}$ achieved its goals mainly through public campaigns, articles, rallies, demonstrations, and taking advantage of social media to get the widest coverage. All of the CCC (2016) activities are rooted in the first principle of the campaign: "All workers, regardless of sex, age, country of origin, legal status, employment status or location, or any other basis have a right to good and safe working conditions, where they can exercise their fundamental rights to associate freely and bargain collectively, and earn a living wage, which allows them to live in dignity." In fact, many of these assumptions have a basis in the International Labour Organization's (ILO) Conventions and Universal Declaration on Human Rights.

The CCC (1998) added to the aforementioned basic principles, presenting a code of labour to be used as a guideline for employers in the garment industry. It stresses three basic rules:

1) The company has to recognize their responsibility not only for its regular employees, but also those working on the production of the article abroad.

2) The company must ensure that all of the employees subordinated to it along its supply chain are subject to ILO standards, and are granted proper working conditions and a living wage.

3) Observance of this code should be a necessary condition in making agreements with other companies.

The campaign argues that 'proper working conditions' means a workplace that is safe, free from any form of abuse of the worker, and ensuring their fair treatment. The maximum number of working hours per week should never exceed 48 , and one day off should be provided each week. The wages should at least meet the criteria set by law, and at the same time be high enough to provide for a decent living for the worker. What is more, some part of the wage should be left for the discretionary use of a worker.

The CCC also focuses on two more very important aspects. The first one is the right of the public to know about the situation which the outsourced production workers are in. Not only does the campaign want to raise people's awareness of the subject, but it also argues that the public itself should take action in helping to make sure that garment industry workers' rights are respected. Perhaps even more importantly, the CCC recognizes that the true key to improving the workers' situation is educating them on their rights. When they are taught what laws are protecting them and how they can use them, they receive the tools which allow them to fight for their own rights. One of the biggest such events, the International Forum (IF) in Turkey, took place in 2009 (CCC 2010). During the four-day conference, the $\mathrm{CCC}$ and its partners held a large number of gender and living 
wage discussions, showed films related to labour issues, and they raised the topic of occupational safety and healthy working conditions and the issue of increasing the organizational capacities of the workers. The IF noted especially positive feedback from the participants of educational sessions concerning bargaining and campaigning techniques as well as the effective usage of social media. The event was a great success, bringing together over 230 participants (including labour union activist as well as the workers themselves) from more than 50 countries and joining them in some 90 workshops.

Thanks to the large number of organizations that are working with the CCC on a partnership basis, the campaign is able to launch events globally and with heavy involvement from the public. In 2004, working in unison with Global Unions and Oxfam, the CCC created one of the biggest and most easily recognizable campaigns for raising public awareness regarding issues of workers in developing states: Play Fair at the Olympics. As reported by the CCC (2004): "Hundreds of organizations and many top athletes have participated in over 35 countries and more than half a million signatures have been collected in support of the campaign." It received wide acknowledgment from the European and British parliaments. Following this success, the CCC led a lobbying group which created the Programme of Work. At its core, the programme advocated freedom of association, creating an environment in which this is enabled, and supporting the workers in this right. It received positive feedback from Puma, Adidas and Reebok. Play Fair at the Olympics has gained such huge recognition that it has since become a recurring event organized by the CCC and its partners.

In 2007, the International Campaign Forum was organized in Bangkok. It was another major event, bringing together participants from over 40 countries. Working jointly with the Centre of Education and Communication and the Thai Labour Campaign, the CCC created the biggest anti-sweatshop event to date. The main issue raised was to devise plans and strategies that would help in the launch of future campaigns. At that time, the CCC addressed a letter to UN special representative, John G. Ruggie (CCC 2007), in particular arguing for the need to create a proper legal framework of control for human rights and stressing the importance of full transparency of corporations' supply chains, so that no violations can take place. The response from the representative acknowledged all the issues and proposals of the CCC, which would in later years take the form of the proposed office of the ombudsperson.

The CCC has been involved in a multitude of other multinational projects but what is also very important in the campaign's activities is the smaller scale on which the CCC operates, as well as the day-to-day work. Things have become much easier for the campaign since 2009, when it started to make its Internet activities much more prominent, launching a blog, a Facebook page, and a twitter account. Aside from publishing posts in many forms on a daily basis (articles, links, pictures), the CCC interacts with the public as well as corporations. The 
campaign invites the people to participate in events, helping them raise awareness and popularity, such as \#free $23^{2}$ and \#weneed $177^{3}$. One of the most wide spread is definitely \#PayUp. It is an action aimed at all the companies that had their production facilities in the Rana Plaza Factory in Bangladesh, and it fights for the remuneration for families and the workers who died or were injured in the collapse of the factory building in $2013^{4}$.

The campaign is involved in a great number of actions simultaneously and is achieving success in the many fields and areas it advocates in. To follow the example of Bangladesh, several cases can be mentioned that are presently the focus of the CCC (2015a). Firstly, since the catastrophe at the Rana Plaza Factory, the campaign has been fighting for compensation for all of the victims, pressurizing Western corporations and holding them responsible for the tragedy (although many of the companies paid, brands such as Carrefour or United Colors of Beneton still neglect their responsibility). So far it has successfully collected over USD 20 million, with the goal being USD 30 million. Another tragedy that demands compensation is the Tazreen Fashions Factory fire in 2012 that killed some 112 workers and left over 100 injured. In 2014, the CCC managed to negotiate a preliminary agreement with C\&A to provide short-term as well as some long-term compensations for the victims. In accordance with its goals, the campaign also fights for workers' rights to unionize. In 2014, after putting pressure on C\&A, Zeeman and KiK, an agreement was reached that allows the Chunji Factory workers to form unions 5 . As presented on their website, the CCC states that: "Whilst C\&A and KiK denied their responsibility, Zeeman engaged with their supplier on the issue. In late August 2014, a positive agreement was reached between the factory management and the union, in which it has been agreed that all charges will be dropped, dismissed workers will be reinstated with back wages and that the factory will respect the right to organize." (CCC 2015c).

One may then ask the question: are the actions of the CCC having an effect? The answer should certainly be: Yes. While it is true that the cases discussed in previous paragraphs (the wage struggle in Cambodia, remuneration for victims in several factories incidents, events for workers' education, and raising public awareness) may sometimes seem insignificant, for example, because they often concern one factory or area, the CCC is involved in a great number of such incidents. Brought all together, they mark a tremendous success, truly contributing to a change in public understanding, corporations' approaches and strategies, and even government policies. With its growth, the CCC is expanding and, as a result, is gaining more partners and influence to utilize in pursuing their goals. The

\footnotetext{
${ }^{2}$ Concerning the imprisonment of 23 workers in Cambodia that tried to unionize.

${ }^{3}$ Fighting to raise the minimum wage in Cambodia to USD 177 for garment industry workers.

${ }^{4}$ On April 24 2013, the Rana Plaza Factory building collapsed, killing 1,133 workers and injuring over 2,500, making it the greatest tragedy in a garment industry factory. It was later established that the building was not suitable for heavy industrial machines, only commercial and retail purposes.

${ }^{5}$ Four workers in the Chunji Factory, Dhaka, Bangladesh were fired for trying to unionize.
} 
campaign is quite likely to continue its development and activities. The issues of workers which are present in garment industry are too significant to be dealt with swiftly. In order to deal with them effectively, a strict and fruitful cooperation between all of the agents, i.e. governments, clothing corporations, factories and the workers themselves, is necessary. The CCC's support in shifting attitudes is not without importance. However, for now, the actions of the Campaign represent the proverbial "stick"; in general, the focus is on pressuring multinational garment industry companies in the many different ways mentioned in this article.

\section{Conclusions}

The situation of the workers in developing states is very poor, as the brief example of Bangladesh tried to underline. Despite some positive economic indicators, the factual situation is much less appealing. Western corporations use those workers as a cheap labour force, rejecting their responsibility for the conditions in these countries. The existence of organizations such as the Clean Clothes Campaign is undeniably very important and their work in the area of CSR is not going unnoticed. The campaign concludes that the workers, because of lack of education and often drastically low living conditions, cannot fight for their rights themselves. Therefore, it aims at educating the workers so they can lift themselves from oppression and the state of reliance that they are in. Besides that, the CCC raises the public's awareness through many actions and campaigns, demonstration and rallies, and more recently with the use of social media like Facebook. The aim is for people to learn about the conditions in which their apparel and footwear is made, and also to invite them to get involved in helping alleviate this situation. Because of the ease in which information travels nowadays, and how the people can become a part of this socially responsible movement, it can only be assumed that it will further gain in popularity. Despite the frequent lack of cooperation on the part of Western corporations, the CCC successfully achieves its goals, be it pushing for union agreements or fighting for remuneration for the victims of poor treatment or accidents. In recent years, the campaign has also gained massive acknowledgment from the EU, being invited to discussions about anew EU initiative concerning the topic of CSR and responsibility for the entirety of the supply chain.

In conclusion, both the CCC (as well as other such units) and the notion of CSR are, to a certain effect, dependant on each other. It can be safely assumed that the need for socially responsible behaviour will not only prevail in the coming years, but also become more important. Its growth will likely be attributed to several different factors, one of which will be the demand from the public for fair business practices. The trend that can be seen in the previous years is clear: people do not like unethical behaviour of companies, they are highly aware of the situations happening in developing states where human rights are violated, and they 
generally express the opinion that precisely because of the power that huge, multinational corporations hold, they should contribute to overall social and economic development. The second factor which plays a role in forcing the future progress of CSR can presumably be governments (this includes the EU) as part of their sustainability strategies. Thirdly, such actions as the CCC will likely continue to have an impact on this notion, through the use of the tools already in its possession and perhaps new strategies in which they shall promote the idea of CSR. Nevertheless, one should also recognize that the main agents in successfully fulfilling the goals of a socially responsible business are the corporations themselves.

\section{References}

Bangladesh Bureau of Statistics (2011), Report on Labour Force Survey 2010, http://203.112.218.66/WebTestApplication/userfiles/Image/Latest\%20Statistics\%20Release/LFS\%20Report\%202010.pdf (last accessed: 16 September 2016).

Bangladesh Bureau of Statistics (2015), Population and Housing Census 2011, www.bbs.gov.bd/WebTestApplication/userfiles/Bangladesh_glance.pdf (last accessed: 16 September 2016).

Carroll B. Archie (1999), Corporate Social Responsibility: Evolution of a Definitional Construct. "Business \& Society", Vol. 38, No. 3, September.

CIA The World Factbook (2016). Bangladesh,https://www.cia.gov/library/publications/the-world-factbook/geos/bg.html, (last accessed:16 September 2016).

Clean Clothes Campaign (1998), Code of Labour Practices for the Apparel Industry Including Sportswear, www.cleanclothes.org/resources/publications/ clean-clothes-campaign-model-code-of-conduct (last accessed: 16 September 2016).

Clean Clothes Campaign (2004), Olympic Report, http://fairolympics.org/background/olympicreporteng.pdf (last accessed: 2 March 2017).

Clean Clothes Campaign (2007), Clean Clothes Campaign letter to John Ruggie, https://business-humanrights.org/sites/default/files/media/bhr/files/Clean-ClothesCampaign-letter-Ruggie-23-Mar-2007.pdf (last accessed: 7 March 2017).

Clean Clothes Campaign (2010), International Forum Special, Threads, Clean Clothes Campaign Newsletter, 2010, No. 30, https://cleanclothes.org/resources/newsletters/ccc-newsletter-threads-no-30-international-forum (last accessed: 17 September 2016).

Clean Clothes Campaign (2011), Annual report 2011, www.cleanclothes.org/ about/annual-reports/2011-annual-report (last accessed: 2 March 2017).

Clean Clothes Campaign (2014), Wage struggle continues, https://www.cleanclothes. org/ua/2014/cases/cambodia-wage-struggle (last accessed: 2 March 2017).

Clean Clothes Campaign (2015a), Cases in Bangladesh, https://cleanclothes.org/ ua/2014/maps/map-bangladesh (last accessed: 2 March 2017). 
Clean Clothes Campaign (2015b), Clean Clothes Campaign Contribution to the Informal meeting with stakeholders on responsible management of the supply chain in the garment sector - European Commission - 23rd January 2015 - Brussels, https://cleanclothes.org/img/pdf/ccc-contribution-flagship-initiative (last accessed: 2 March 2017).

Clean Clothes Campaign (2015c), Chunji workers win right to organize at facto$r y$, https://cleanclothes.org/ua/2014/cases/chunji-knit (last accessed: 2 March 2017).

Clean Clothes Campaign (2016), The principles of Clean Clothes Campaign's work, www.cleanclothes.org/about/principles (last accessed: 2 March 2017).

Clean Clothes Campaign (2017), Who we are, www.cleanclothes.org/about/whowe-are (last accessed: 17 June 2017).

European Commission (2014), Informal Meeting with Member States on Responsible management of the supply chain in the garment sector, http:// ec.europa.eu/transparency/regexpert/index.cfm?do=groupDetail.group DetailDoc\&id=16999\&no=2 (last accessed: 1 March 2017).

International Labour Organization (2015), Fundamental Conventions, www.ilo. org/wcmsp5/groups/public/@ed_norm/@declaration/documents/publication/wcms_095895.pdf (last accessed: 7 March 2017).

National Institute of Statistics and International Labour Organization (2010), Labour and Social Trends in Cambodia 2010, www.ilo.org/wcmsp5/groups/ public/---asia/---ro-bangkok/documents/publication/wcms_158511.pdf (last accessed: 2 March 2017).

The Observatory of Economic Complexity (2016), Bangladesh, http://atlas.media.mit.edu/en/profile/country/bgd/ (last accessed: 2 March 2017).

The Observatory of Economic Complexity (2016), Cambodia, http://atlas.media. mit.edu/en/profile/country/khm/ (last accessed: 2 March 2017).

Trading Economics (2016), Bangladesh, www.tradingeconomics.com/-bangladesh/gdp-growth (last accessed: 2 March 2017).

Trading Economics, Cambodia, www.tradingeconomics.com/cambodia/gdp (last accessed: 2 March 2017).

US Department of State (2013), Bureau of Democracy, Human Rights and Labour, Bangladesh - Country Reports on Human Rights Practices for 2013, www. state.gov/documents/organization/220600.pdf (last accessed: 2 March 2017).

\section{Summary}

The aim of the article is to investigate the Clean Clothes Campaign (CCC) organization and its efforts to alleviate the poor situation of workers in developing states and to promote the idea of Corporate Social Responsibility. It starts with a brief example of two such developing countries, Bangladesh and Cambodia, data for 
which has been drawn from Eurostat, Trading Economics, and the CIA's World Factbook. It then moves to its main focus, that is, the description of the structure of the CCC, the different ways in which it tries to achieve its goals, and the vast network of partnership between the campaign and NGO's worldwide, as well as the cooperation with decisive bodies of the European Union. The article concludes that the work of the CCC is very important and is getting more and more recognition in recent years, both from formal bodies and the public.

Keywords: Clean Clothes Campaign, Corporate Social Responsibility, developing states

\section{Streszczenie}

Społeczna odpowiedzialność biznesu w przemyśle odzieżowym - Clean Clothes Campaign a państwa rozwijające się

Celem artykułu jest przeanalizowanie działań organizacji Clean Clothes Campaign podejmowanych w celu polepszenia złej sytuacji pracowników w krajach rozwijających się oraz promowania idei społecznej odpowiedzialności biznesu. Aby lepiej przybliżyć problem, na początku artykułu odniesiono się krótko do dwóch krajów rozwijających się, Bangladeszu i Kambodży (dane zostały zaczerpnięte z Eurostatu oraz stron Trading Economics i CIA The World Factbook). Następnie opisano strukturę CCC oraz metody, dzięki którym organizacja chcę osiągnąć swoje cele. Przedstawiono także szeroką sieć współpracy między CCC a innymi organizacjami z całego świata i organami decyzyjnymi Unii Europejskiej. Reasumując, można stwierdzić, że działalność CCC staje się coraz bardziej istotna, a w ostatnich latach organizacja zyskuje uznanie zarówno organów formalnych, jak i społeczeństwa.

Stowa kluczowe: Clean Clothes Campaign, społeczna odpowiedzialność biznesu, kraje rozwijające się

JEL: A13, F63, M14 